\title{
MENTALITY AS ONE OF THE MOST SIGNIFICANT ATTRIBUTES OF NATION: HISTORICAL AND METODOLOGICAL ASPECTS
}

Liliya Radikovna Sakaeva

Kazan Federal University, Institute of International Relations.

Irina Germanovna Kondrateva Kazan Federal University, Institute of International Relations.

Marat Aidarovich Yahin Kazan Federal University, Institute of International Relations.

Evgeniya Vladimirovna Kuznetsova University of Management "TISBI"

E-mail: liliyasakaeva@rambler.ru

Recepción: 05/08/2019 Aceptación: 09/09/2019 Publicación: 23/10/2019

Gitación sugerida:

Sakaeva, L.R., Kondrateva, I.G., Yahin, M.A. y Kuznetsova, E.V. (2019). Mentality as one of the most significant attributes of nation: historical and metodological aspects. $3 C$ TIC. Cuadernos de desarrollo aplicados a las TIC. Edición Especial, Octubre 2019, 30-43. doi: https://doi.org/10.17993/3ctic.2019.83-2.30-43

Suggested citation:

Sakaeva, L.R., Kondrateva, I.G., Yahin, M.A. \& Kuznetsova, E.V. (2019). Mentality as one of the most significant attributes of nation: historical and metodological aspects. 3C TIC. Cuadernos de desarrollo aplicados a las TIC. Special Issue, October 2019, 30-43. doi: https://doi.org/10.17993/3ctic.2019.83-2.30-43 


\section{ABSTRACT}

The authors prove their thinking as the most important issue for any nation in their writing. Scholars have not reached any agreement on the nature of matter, nature, and personality. It deals with these issues. Every person in a community has a part of a place in the community (a class, a church community, an ethnicity, a state, etc.). That comes from a friend or foe that shows an ancient dichotomy. In a national entity, there is always a prevailing stable thing We call it mentality. A popular individuality cannot be qualified by sole property but by social trait, why. And today, in the visage of a date of the procedure of globalization integration, it is significant to citation this reality.

\section{KEYWORDS}

Language, Mentality, Nations, Tatar, Greek, Character, Community, Culture, Archetype, Globalization. 


\section{INTRODUCTION}

Ethnocultural and ethnonational revival of self-consciousness of population in the secondary mid of the 20th centenary is one of the main features of the development of mankind at the present stage. This is due to the subject's desire to identify himself as a part of a social community adequately to form his identity in modern conditions complicated by processes of globalization and integration. Any social community, whether ethnic, cultural, religious or linguistic has a complicated structure and complex content defined by the history of its development and interaction. The nature of one or another social community depends on the nature of the identity of its agents (Kalegina et al., 2015; Kashisaz \& Mobarak, 2018). Social communities change from time to time, their earliest type is tribes. Tribes originally consisted of several social "cells" connected with blood ties. Nowadays the term "tribe" represents ethnic groups on different levels of social, economic and cultural development. Some of these tribes are small (include hundreds of people), others are more numerous (number thousands, tens of thousands). Now only nomadic and semi-nomadic peoples have features of tribal organization. Gradually, the communal operation decayed, tribes united in unions, such as the League of the Iroquois in North America or Tatar-Mongols in Eurasia, they replaced blood links and formed a new type of ethno-social community - peoples (Baykalova et al, 2018; Kheirabadi \& Mirzaei, 2019).

The first peoples were formed in the slave era. There were ancient Egyptians, ancient Greeks and Romans. Later drevlyane, krivichi, vyatichi formed ancient Russian people. As ethnic processes taking place during the whole period of existence of humanity, are quite complicated and varied, there is nothing surprising in the fact that many scientists appeal to their investigation. With the beginning of the formation of states a new type of ethno-social collectivity nation - begins to form itself. Nation as a product of era of modern times has become a completely new form of social community. Understanding of nation in different countries has been always different. In France, nation is a state, part of the civilization and it's distributed by urban bourgeois values. In Germany, nation is a community united by language and culture. In England the notion of nation 
relates to the notion of "Anglican Church". In the 16th century, the national consciousness had bright religious overtones when the Pope seemed to be the enemy of the nation. Another feature of the national consciousness of Britons is imperialism, formed due to the large number of British colonies. We can agree here that era of worldwide victory of capitalism over feudalism was associated with national movements. The formation of national states is the tendency of any national movement.

\section{METHODS}

As the history of nations is complex and controversial, the concepts of nation, ethnos, mentality are also complex and controversial, and the processes of globalization and integration make the problem of national identity serve as a key in defining of identity. Today, most oppositions in the reality of our people's social lives turn into a lack of awareness of social history, a misunderstanding of their conscious and subconscious ways that is usually hidden in the ethnic mindset of society. The difference between one nation and another lies in their thinking. This characteristic is understood from the generality of personality traits and behavioral traits. Philosophical research in society reveals many ways to teach and differentiate between clear principles and analysis, which in our view is the goal of philosophy in the unified theoretical analysis of the nature of thinking. We have said before that there is no difference knowledge and the nature of national personality from the point of view of scientists, but through various studies we address the problem of national personality and the cultural and historical significance of subjectivity. Due to the different approaches in the historical process we use the following historical and systematic comparative method. At the same time, the systematic approach helps to analyze the problem from different perspectives. 


\section{RESULTS AND DISCUSSION}

We must believe that the inner properties of different nations are not the same, and simply because of the old dichotomy (enemy, friend) this happens in different nations and people. Even in those primeval times, there were many descriptions of the way of life, personality traits and moral values of different nations. In ancient times, however, knowledge of the individual traits of each nation was studied in a descriptive, stored fashion, with only a practical focus, but has changed over time. At that time, the sciences were growing rapidly, leading to a comparative study of nations (history, geography, anthropology and linguistics), a profound and complete inference of acquired ethnological information. A modern theoretical model emerges that focuses on learning the facts about human behavior, but there are numerous variations in the activity of the masses of nations: for the first time they have made decisions about the historical destiny of their lands. In addition, the process of the creation of the European nations was accelerated. Since then, all these issues have prompted differences of opinion between different ethnicities to shift the issue of unpleasant interest and scientific analysis to many scholars. In the course of the twentieth century, educational questions about the character of a nation, its subjectivity, and the form of their historic substantiation are transforming into a research linking a national mind set and nature. Gimilf thinks that a national plural character is no more than a legend.

According to Gimilf in Year 5, while preserving the ethnological phase sequence for each new era, the personality traits of each nation always change according to a real situation, so a national character should not be regarded as a sustainable and liberal learning. A Gimblef illustrator cites the moving forces of a Russian national popular character, traits that have been traced back to different historical periods. In his work, Trofimov calls this methodological relativism. It shows Russian idea, roots, nature, and social cultural revelations, so the explanation of the national character means a period of historical sways, but the durability of some traits is declined. Some prevailing exegesis of the complexity of national character and subjectivity in modern scientific literature lead to the form of research studies. 
The new scientific literature of the national personality is described as follows:

A. Psychological attribute that exists in all peoples of one nation that makes the difference between each person and another.

B. Pack of psychological characters that most people in that country have.

C. A kind of character which is indicates arbitrary, classical for the people.

D. Generic traits of conducts and mentality, which typescripts diverge from a countrywide art.

E. A preferable method of intelligent, which is articulated in structures of a countrywide character.

F. A set of values, standards, inducement which regulates the lifestyle of states.

Such explanations imitate two kinds of organizational sets in defiance of a state personality, which are ethno psychological and ethno cultural. Both of types are subjected to a realistic reproach for its narrow-mindedness. From the point of ethno-psychologists a countrywide character is a historically industrialized set of constant psychological behaviors of executives for other ethnic clusters, which regulates their usual routine in attitude to a social medium, external things and to its and other ethnic communities. A national character is described by the totality of the characteristics and traits of a community whose only character is in its culture. In the works of the largest American sociology of Russian character, to understand a national character, the ethnic psychological approach has been heavily criticized. Sorokin paid attention to the secondary choice of individual and unique characteristics. they are not undistinguishable to characteristic landscapes of a prepared group and vice versa (Sorokin, 2010; Hasbullah \& Wibawa, 2017; Eslami \& Ahmadi, 2019).

Sorokin (2010) thought that attitude to a personality and nation is an individual case of a single and general dialectic, individual and origin. Certainly, a person has traits, which characterize the nation overall. Of a great number of individuals have specific national character traits. 
Fromm (1989) tried to understand a dynamic nature of a national character, its relationship with characteristics of a socio-cultural existence in his works. $\mathrm{He}$ explained many changes in a social transformation through discovery of a social potential of a national character. Particularly, he used the concept of a national character in a process of understanding the reasons of Nazism coming to a power in Germany. From his point of view, for German nation is inherent such qualities as love to a strong and hatred to a weak, limitation, stinginess in feelings and moneys. These qualities have formed that «social and human foundations», which became a favorable condition to an increase position of Nazism. But national character cannot be only reduced to the ways of behavior; it's a complex, common mechanism of a nation adaptation to one or another natural, social condition of its existence.

Many scientists point out that a national character is a "set of some traits of a spiritual character of a nation, which appears in its own traditional forms of a behavior and the perception of the environment" (Bloom, 1993). In the interpretation of Boas (1930), a national character is a common and personal elements and structures of any cultural traditions, which provide common or (its dominant) forms of a worldview, behavior and mentality. A national character is the most complex socio-cultural phenomenon, which is developed in different kinds of cultural activities. But for the last ten years, the term a "national character "is substituted for "mentality" (Boas, 1930). Representatives of a historical school in France have made a significant contribution to the research of mentality category. Jacques Le Goff distinguishes two kinds of reality as a material reality and the idea of this reality (mentality). Mentality is an independent and very important part of a historical process, but it is interpreted ambiguously: as a group view and manners; as modes of thought and sensation; as ethical codes and symbols.

For Gurevich (1999) mentality is a "live, changeable and for all that a detecting stable constants of life directions and manners, which depends on deep zones, inherent in that community and cultural traditions". Mentality reflects and realizes the picture of the nation's world, inherited from the previous generation 
and its life aspects which underlie them. The variety of mentality is a national mentality, original, modern equivalent of the term "soul of nation". In social philosophy there is a term «national mentality», as well as the terms "soul of nation", "national spirit", they are synonymic and used for description of cognate to its own inner world of spiritual and social aspects of ethnos and nations' life.

\section{SUMMARY}

The analysis that we have made, let us draw a conclusion that the concept of mentality is close to its meaning as an archetype and ideology. By comparing mentality and archetype, it should be pointed out what have in common is that they represent a group idea of people, an unconscious level of conscience. But archetypes, inherited by people from their ancestors are all same of individuals and social groups. Mentality is more dynamic and has a differentiated character. Like ideology, mentality relates to the interests of special social groups and has an influence on conceptualization of events of a political, economic and sociocultural character. But if in ideology, the social community realizes its interests and can formulate them as a theoretical contraction, but mentality is an unconscious level of a spiritual life and cannot be entirely expressed in rationally theoretical forms.

Different determinants can be pointed out during interpretation. Naturocentrism orientations appear in exaggeration of natural climatic causes in the formation of a mentality. For example, the theory of C. Montesquieu can be related to it; who is a representative of the geographical determinism about a decisive climate influence on people's character or O. Bauer's views on an inherited mechanism of essence of a nation. Theocentrism is in an acceptance of a dominant role of a religion. Chaadaev (2014) explains some traits, which are inherent in Russian nation as a (submission, incapacity to persistence, indifference to kindness and evil, truth and lie) by the influence of Orthodoxy. Sociocentrism overemphasizes socioeconomic determinants in formation of the mentality. There is a methodological basis of this approach in Marxism. As regard this, Engels (1955) writes that English 
workers and bourgeoisie was completely different people. Anthropocentrism notes that there is a meaning of upbringing in the understanding of a mentality. E. Erikson calls Russian soul as «a twisted soul». He notices that in Russia a tight child diapering relates to an unconscious need to convey the feeling of "a tight hand" (Erikson, 2009).

\section{CONCLUSIONS}

Man as a person always develops under a powerful influence of many social groups, in which he is a part of it and who takes part in achievement of his "inner self". Sigmund Freud pointed out several times, that every person is a component part of some social community. He and some other scientists noted that every person is a part of a class, church's community, ethnos, state, etc. (Freuds, 2011). In the process of socialization, a person forms socio-cultural (including ethnonational) norms, importance and values, as a result of it he gains a national identity, allowing him to consider as a bearer of a certain national mentality. Mentality is a dominant constant of a national existence, and today, against a background of globalization integration processes, it's important to define correctly mental traits each of nations and determine the reasons, that have caused specific traits to avoid possible cross-cultural conflicts. We should remember that the mentality of each nation is a unique and there are no good and bad nations. According to conditions, the same mental nature can be strong, weak and weak points of ethnos conscience. A modern socio-cultural situation makes its demands to learn the mentality issues, and today it's very important how a mental trait or set of traits can define behavior of people and have an influence on acts its separate representatives, what is role of the mentality of an ethno- national community in its today's interaction with other ethno- national communities.

\section{ACKNOWLEDGEMENTS}

The work is performed according to the Russian Government Program of Competitive Growth of Kazan Federal University. 


\section{REFERENCES}

Baykalova, E. D., Artyna, M. K., Dorzhu, N. S., Ochur, T. K., \& Mongush, D. S. (2018). Morphological interference in the process of mastering English speech in conditions of interaction of Tuvan, Russian and English as a foreign language. Opción, 34(85-2), 35-60.

Bloom, W. (1993). Personal identity, national identity and international relations (Vol. 9). Cambridge University Press.

Boas, F. (1930). Some problems of methodology in the social sciences. The new social science, 84-98.

Ghaadaev, P. Y. (2014). Stat'I I pis'ma, Moscow: Izd. "Modern Man”, 280s.

Engels, F. (1955). Polozhenie rabochego klassa v Anglii [Condition of the Working Class in England]. Marx, K. E̊ Engels, F. Sochineniya.

Erikson, E. (2009). Detstvo I obschestvo, SPb.: Izd "Lenato", "AST", "University Book", 540s.

Eslami, R., \& Ahmadi, S. (2019). Investigating the Role of Educational Media on Secondary School Students' Learning Process Improvement in Jahrom City. Fournal of Humanities Insights, 3(01), 13-6. doi: https:/ / doi.org/10.22034/ jhi.2019.80890

Freuds, S. (2011). Uber der Traum, Munchen, 411 p.

Fromm, E. (1989). A man for himself, Cambridge University Press, 288p.

Gumilev, L. N. (2010). Ot Rusi k Rossii, Moscow, Izd. "D-Dick", 542s.

Gurevich, A. Y. (1999). Mental'nost', Moscow: Izd. "Progress", 464s. 
Hasbullah, \& Wibawa, B. (2017). Analysis of Mathematics Students Ability in Learning Metacognitive Strategy Type Ideal (Identify, Define, Explore, Act, Look). International Electronic Fournal of Mathematics Education, 12(3), 859-872. Retrieved from https://www.iejme.com/article/analysis-of-mathematicsstudents-ability-in-learning-metacognitive-strategy-type-ideal-identify

Jabbari, E., Charbaghi, Z., \& Dana A. (2019). Investigating the Effects of Educational and Motivational Education at Different Levels on the Performance and Application of dart throwing. Fournal of Humanities Insights, 3(02), 37-44. doi: https://doi.org/10.22034/jhi.2019.80896

Kalegina, T. E., Takhtarova, S. S., \& Zaglyadkina, T. Y. (2015) Denglish and Franglais in the framework of the modern European linguistic landscape. Fournal of Language and Literature, 6(3), 195-198. Retrieved from http://dspace.kpfu.ru/xmlui/bitstream/handle/ net/142405/SCOPUS 20780303 -2015-6-3-SID 84959051476 -a 1. pdf;jsessionid=E97E1A2175E20B5E97CF759667A96BFB?sequence=-1

Kashisaz, S., \& Mobaraki, E. (2018). The Effects of Private Education Institutes in Providing Modern Financial Knowledge in Developing Countries. Fournal of Humanities Insights, 02(04), 172-8. doi: https://doi.org/10.22034/ jhi.2018.80887

Kheirabadi, M. A., \& Mirzaei, Z. (2019). Descriptive valuation pattern in education and training system: a mixed study. Fournal of Humanities Insights, 3(01), 7-12. doi: https://doi.org/10.22034/jhi.2019.80889

Nakhaee, J., \& Nasrabadi, M. A. (2019). Strategies for Research-Centered Education of Architectural Designing by Examining the ResearchCentered Activities of the Top Universities. Fournal of Humanities Insights, 3(02), 50-6. Retrieved from: http://www.jhumanities.net/article_80898_ dcaa625489b5f0ff63aea1583a374ee8.pdf 
Sakaeva, L. R., Sabirova, D. R., \& Kuznetsova, E. V. (2018). Culture and civilization: functional and methodological aspects. Revista Publicando, $5(16$ (1)), 435-442. Retrieved from https://revistapublicando.org/revista/index.php/ crv/article/view/1514

Solnyshkina, M. I., \& Ismagilova, A. R. (2015). Linguistic landscape westernization and glocalization: The case of Kazan, Republic of Tatarstan. XLinguae, 8(2), 36-53. doi: https://doi.org/10.18355/XL.2015.08.02.36-53

Sorokin, P. A. (2010). Glavnye kharakternye cherty pusskogo naroda v XX veke, Moscow: Izd. «Nauka» pp: 563s.

Tavana, M., Chamaneh, R., \& Chahe, T. (2019). The relationship between personality and mental health of employees Healthcare network in Sabzevar city. UCT Journal of Social Sciences and Humanities Research, 7(1), 8-12.

Travers, A. (1995). The Self Identification. Oxford, 340p.

Trofimov, V. K. (2002). Russkaya mental'nost': proiskhozhdenie, priroda, sotsiokul'turnye proyavleniya, Izhevsk: UDGU, 238s. 
Edición Especial Special Issue Octubre 2019 DOI: https://doi.org/10.17993/3ctic.2019.83-2.30-43 